Rajend Mesthrie. A Lexicon of South African Indian English, 1st edition 1992, xxix + 148 pp. ISBN 09488310 6. Leeds: Peepal Tree Press. Price Ł7,95.

\title{
Introduction
}

Mesthrie's statement on $\mathrm{p} . \mathrm{i}$ that this Lexicon is intended to supplement the 1980 edition of $A$ Dictionary of South African English (ed. Jean Branford) with reference to South African Indian English, the second largest (sub)dialect of English in South Africa, locates the book under review in the context of the study of English as a world language. First published in 1992, this book arises out of research commenced in 1985, and documents the state of South African Indian English from the earliest acquisition of English by the South African Indians (basilect forms of English) with focus on their contribution to the language. Mesthrie notes that the variety South African Indian English is a valid development of the English language, in the same category as Indian English or Caribbean English. This study pertains to the language in KwaZulu-Natal.

The persistence of features of South African Indian English in the English usage of South African Indians, and the appearance of new lexical items underline the significance of Mesthrie's contribution while pointing to the need for continued work in this field.

\section{Method and format}

The writer enumerates the sources, including personal experience, student projects and interviews with speakers and written sources such as newspapers with an Indian readership. He does not mention sources such as dramatic performances at weddings etc., which also captured South African Indian English usage; however, the Lexicon includes items used in such performances.

The format employed facilitates the distinction between various different usages: items used by most speakers irrespective of ancestral language, items peculiar to subgroups of a particular ancestral language, idioms and phrases, grammar, slang, pronunciation and general South African English items in South African Indian English. In this way Mesthrie has succeeded in giving a precise background and description of the item or usage. Furthermore, labels such as rare, historical, rural and basilectal help to categorize the items, e.g.:

\section{COLD-TOUCH n.}

A cold, a touch of cold. Bas. (p. 11)

\section{DOSH n.}

A small container for holding snuff, usually made of tin. Rural areas. Now rare. [Zulu idosha] 
Etymologies from the relevant Indian substrate language are provided. These often refer to more than one substrate language. The introductory part of the book also provides abbreviations as well as symbols and spelling conventions.

\section{South African Indian English}

In an introductory essay "South African Indian English", Mesthrie discusses, inter alia, the genesis of South African Indian English from around 1878, and explains why this dialect is not a pidgin or creole but rather a creoloid (after Trudgill, Platt and Todd). Mesthrie asserts that South African Indian English is a "model for the second language English of more and more young Zulu speakers in parts of rural Natal" (p. xvii). While this attests to the widespread influence of this form of English, the writer also expresses concern about the survival of many items of this language, with the loss of domains of usage consequent upon religio-cultural changes.

I do not unreservedly share this concern, in view of the dramatic changes wrought by the process of democracy in South Africa. The social, cultural and political milieux which generate forms and types of language, and which dictated the need for the development of South African Indian English, in the present period promise to empower the various languages in South Africa. Cultural and ethnic identity, liberated from apartheid's negative connotations, engender pride in one's heritage. South African Indian English, as well as South African English will be enriched by lexical items arising from the sociopolitical milieu, e.g. the biryani bunch (Indian politicians entertaining apartheid leaders with biryani) and the House of Deli-goats (House of Delegates). More positive contributions will emerge from politics, music, arts, culture, literature, diplomacy and tourism. Moreover, as Mesthrie concedes, "the early history of South African Indian English has yet to be fully uncovered" ( $p$. xxiii). To this, one could add that a more comprehensive study of this subject, important to the study of the contributions of the Diaspora Indians, as well as the development of the English language, awaits the scholar.

\section{The Lexicon}

Mesthrie has applied the same painstaking 'scientific skills to this Lexicon as is evident in his other works. The Lexicon, a valuable source book for students of languages and linguistics, is also an appealing, readable book for non-specialists and laypersons. The largest section of the Lexicon deals with South African Indian English used by most speakers (Indians) irrespective of their ancestral language. The sources of these items are various: Hindi, Gujarati, Arabic, Sanskrit English, Tamil, Telugu, Zulu. It is notable that words from Afrikaans are not included here since they more properly constitute part 
of South African English (SAE).

In the 50 pages making up Section Ia, Mesthrie has collected an interesting range of lexical items which can be easily identified by "native" speakers of South African Indian English. The wide variety of sources, including Zulu, attests to the assimilative nature of language generally, and the linguistic openness and ingenuity of the Indian people. This has contributed to the enrichment of the English language in South Africa; and would probably add to the treasury of English with exposure of South African writing internationally. The items refer to various aspects of the Indians' lives in South Africa; from the politically oppressive (AFFECTED AREA, p. 1), cultural practices (BACK SARI, p. 2) to religion and various culinary entries. Items such as BIG-SISTER (p. 6) and COUSIN-BROTHER (p. 13) (as well as COUSIN-BIG-FATHER, COUSIN-SISTER, COUSIN-BROTHER-IN-LAW) point to both the inadequacy of the English language regarding precise terms of relationships, as well as the Indians' adherence to traditional relationships, with emphasis on affection, respect and the extended family. It is also interesting that many lexical items, with Indian substrates, are applied in a context peculiar to South Africa. The word GADHRA derives from Hindi/Urdu and became attached to the mature (but not dried) bean seeds in Natal. Gadhra-beans seems to be the popular description for the seeds of beans (like fresh peas, lima beans) and is used in many chain supermarkets in the province of KwaZulu-Natal. Colloquialisms, swear words and some quaint expressions such as GOAT-PRAYERS (p. 19) persist in the speech of the South African Indians.

The basilectal components of South African Indian English, prevalent amongst the different linguistic groups, reflect on the source languages while indicating the Indians' determination to bend the English language to their use. Many examples of the basilectal expressions have been listed, e.g. FUTURE (p. 18) for fiancé or fiancée, GOING-TIME (p. 20) and INDEPENDENT (p. 24) for haughty, aloof. A more assiduous search and documentation of the basilect of South African Indian English would yield interesting results.

Section Ib lists items "limited to certain subgroups, dependent upon ancestral languages" (Indian languages). While this categorization is generally valid, there has been much interlinguistic contact and words such as AKKA, AMMA (p. 51) and many others are used across the linguistic spectrum. A linguistically interesting feature is the seeming "Anglicization" of Hindi (Bhojpuri) verb roots, e.g. bhuj (roast) becomes bhujo in usages such as "let us bhujo some meat", extended to bhujo-ing in participial forms. In South African Indian English the -0 ending is added to many Hindi/Bhojpuri/Urdu verbs. In Caribbean (Trinidad) English the verb is given an -e ending to make it part of the spoken English, e.g. bele (from bel = roll dough), e.g. let us bele the dough.

Section II notes some idioms and popular phrases, many of these humorous and witty, e.g. TO HAVE A DOUBLE-ENGINE, p. 87 (i.e. to have a lover in addition to a spouse). I am confident that this list can be rewardingly expanded. 
Section III, headed "Grammar", details a variety of departures from Standard English, on the analogy of Indian languages, in which usages for emphasis, auxiliaries and a wide range of grammatical features are recorded. Many of these "aberrations" such as the use of NEVER (I never see him) are found in other groups as well. Likewise, double negation (I never tell him nothing) is not peculiar to South African Indian English.

Section IV lists slangs used in South African English and South African Indian English. The use of slang, though prevalent, is eschewed by mature speakers of South African Indian English, for the simple reason that it is slang.

The Fifth Section deals with the pronunciation of English words in a way peculiar to Indian speakers. In my opinion these words do not necessarily constitute "South African Indian English" in the true sense. These belong more appropriately to the domain of "uneducated" usage of English words, although they may appear among speakers of even Standard English. The word maintenance (p. 123), often pronounced as maintainance by Indians, is also pronounced in this way by other groups. The same applies to NUINSANCE. Other items are speech idiosyncrasies, e.g. AKS for ASK (p. 121).

The Lexicon ends with a list of words common to South African English and South African Indian English. These words belong to various domains of South African life - from "Book of Life" and "conditional exemption" to "bottle store", "butchery", "dagga", and "donga".

\section{Conclusion}

Mesthrie's A Lexicon of South African Indian English, described by the author as a supplement (and also complement) to the 1980 edition of $A$ Dictionary of South African English (ed. Jean Branford) is a valuable and interesting endeavour in its own right. It is a valid contribution to the study of language and should appeal to students of linguistics, sociologists, anthropologists and cultural historians. The Lexicon also adds to the growing body of works on the contributions of the Indian South Africans.

Rambhajun Sitaram

Department of Indian Languages University of Durban-Westville Durban South Africa 